\title{
Removal of silicone breast implants and review of literature
}

\author{
Michael SG Bell MD FRCSC ${ }^{1}$, Gaby D Doumit MD MSc FRCSC ${ }^{2}$, Brian R Buinewicz MD FACS ${ }^{3}$
}

\begin{abstract}
MSG Bell, GD Doumit, BR Buinewicz. Removal of silicone breast implants and review of literature. Can J Plast Surg 2009;17(4):e48e49.

Silicone breast implants have a finite life span and may need changing over the lifetime of the patient. The experience with removing first- and secondgeneration implants is frustrating, because thick capsules often form, in association with rupture and spread of the silicone gel into the surrounding tissue. Different techniques have been employed to try and avoid an unnecessarily large incision, yet still control the dissection so that entire capsule and contained silicone can be removed en bloc. The authors describe a technique that facilitates atraumatic removal using an effective and time-saving vacuum principle.
\end{abstract}

\section{Retrait d'implants mammaires de silicone et revue de la littérature}

Les implants mammaires de silicone ont une durée de vie limitée et peuvent devoir être changés au cours de la vie de la patiente. Le retrait des implants de première et de seconde générations est difficile parce que d'épaisses capsules se forment et sont souvent associées à une rupture de l'enveloppe et à un écoulement du gel de silicone dans les tissus avoisinants. Diverses techniques ont été employées pour éviter les grandes incisions et bien contrôler la dissection afin de retirer en bloc la capsule et la totalité du gel de silicone. Les auteurs décrivent ici une technique qui repose sur un principe d'aspiration efficace et rapide et permet un retrait atraumatique.

Key Words: Ruptured silicone implant removal; Silicone implant complications; Surgical removal silicone gel implants

Cilicone gel breast implants have been used in the United States (US) since 1962 (1). In February of 1992, the US Food and Drug Administration limited the use of silicone breast implants to patients in research studies. In 2006, the US Food and Drug Administration approved the use of silicone breast implants in the general population. The exact number of women with silicone breast implants is currently unknown; however, certain reports indicate that over $3 \%$ of the US female population has silicone breast implants.

Silicone breast implants are not lifetime devices. Their risk of rupture increases with age (2). Holmich et al (3) recently reported a $15 \%$ rupture rate of implants at 10 years. Removal of old silicone implants - ruptured or not - presents several challenges for the surgeon. Trying to minimize the length of the access incision makes visualization of the plane of dissection of the capsule more difficult. Good retraction is critical, as is control of the implant, which must be manipulated in one direction or the other to try and keep the plane of dissection and not enter the capsule, which would cause a spill of the contents.

\section{METHOD}

The authors in two different institutions have used the following identical method for more than 10 years to atraumatically control the manipulation of the capsule and the contained prosthesis.

A $60 \mathrm{~mL}$ Toomey syringe is used without the plunger. The vacuum hose for a liposuction machine or just the regular wall suction is attached to the tip. By applying vacuum to the
Toomey syringe, one then has an ideal suction cylinder that can be applied to atraumatically grasp the capsule containing the breast implant. In many circumstances, the capsule can be entirely removed through a fairly minimal incision compared with the traditional technique. The beauty of the suction technique is that sharp instruments are not used to grasp and manipulate the capsule, which frequently results in a rupture and leak of contained free silicone.

When the dissection has reached the point where the capsule cannot be freed up further, a simple stab incision is made in the capsule, and the vacuum device is used to suction up as much silicone as it will hold. A second syringe can then be substituted, and by this technique the volume of silicone contained within the capsule is reduced by $120 \mathrm{~mL}$. If too much silicone escapes beyond the syringe itself and into the suction tube it may block. One may then choose to simply grasp the capsule with Allis forceps and try to finish a complete dissection with the volume reduced, making removal of the entire capsule and contained silicone much easier (Figure 1).

\section{DISCUSSION}

We have found this simple technique to be a time-saving procedure, with the additional benefit of reducing or more often eliminating contamination of the operative site with liquid silicone. In the case of a ruptured implant, the same technique could be applied to suction the free silicone within the capsule or in the extracapsular tissue. Two reports in the literature $(4,5)$ describe two other techniques to remove silicone gel from

${ }^{1}$ The Department of Surgery, Division of Plastic Surgery, The Ottawa Hospital-Civic Campus, Ottawa, Ontario; ${ }^{2}$ Division of Plastic Surgery,

Temple University Hospital, 3401 North Broad Street, Philadelphia; ${ }^{3}$ Division of Plastic Surgery, Abington Memorial Hospital, 1200 Old York

Road, Abington, Pennsylvania, USA

Correspondence: Dr Michael SG Bell, 402-1919 Riverside Drive, Ottawa, ON, Canada, K1H 1A2. Telephone 613-739-5424,

fax613-739-7168, e-mail msgbell@cyberus.ca 


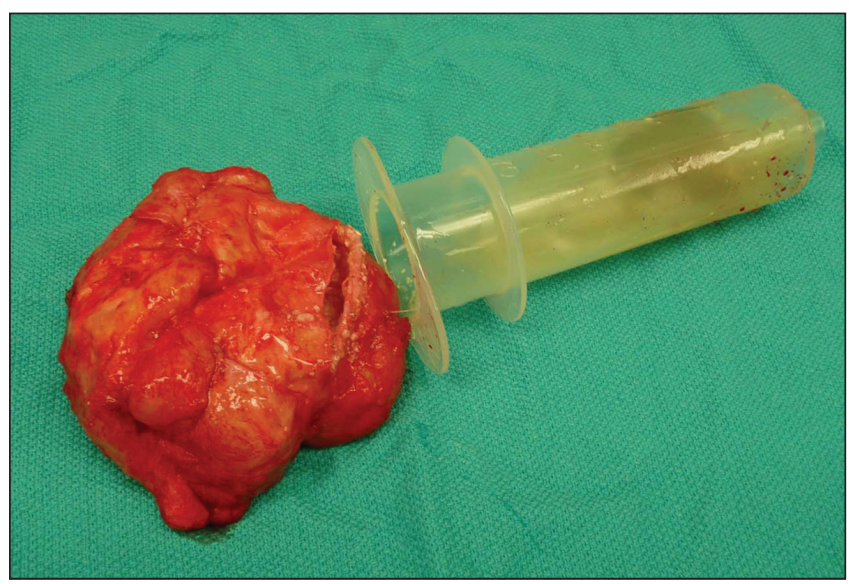

Figure 1) Encapsulated implant decompressed with Toomey syringe

the surrounding tissues after implant rupture. In 2006, O'Neill and Taylor (4) reported the use of a $1 \mathrm{~L}$ saline bottle connected to a 'Baldwin spike adaptor' that is then connected to suction tubing. In another report, Bitar et al (5) described the use of surfactant fluid (Shur-Clens Wound Cleanser, ConvaTec USA) to remove silicone gel from surrounding tissues after implant rupture.

With the reintroduction of new-generation gel implants there will no doubt be ongoing requirements for techniques such as these to facilitate mechanical removal of failed or contracted silicone gel implants, while minimizing local contamination.

\section{REFERENCES}

1. Cronin TD, Gerow FJ. Augmentation mammaplasty: New "Natural Feel" prosthesis. Transactions of the Third International Congress of Plastic Surgery Amsterdam, The Netherlands 1963;51:41-9.

2. Cunningham B. The Mentor Core study on silicone MemoryGel breast implants. Plast Reconstr Surg 2007;120(Suppl 1):19S-29S.

3. Holmich LR, Kjoller K, Vejborg I, et al. Prevalence of silicone breast implant rupture among Danish women. Plast Reconstr Surg 2001;108:848-58.

4. O'Neill J, Taylor I. A novel method to remove silicone gel after breast implant rupture. J Plast Reconstr Aesth Surg 2006;59:889-91.

5. Bitar GJ, Nguyen DB, Knox LK, Dahman MI, Morgan RF, Rodeheaver GT. Shur-Clens: An agent to remove silicone gel after breast implant rupture. Ann Plast Surg 2002;48:148-53. 